
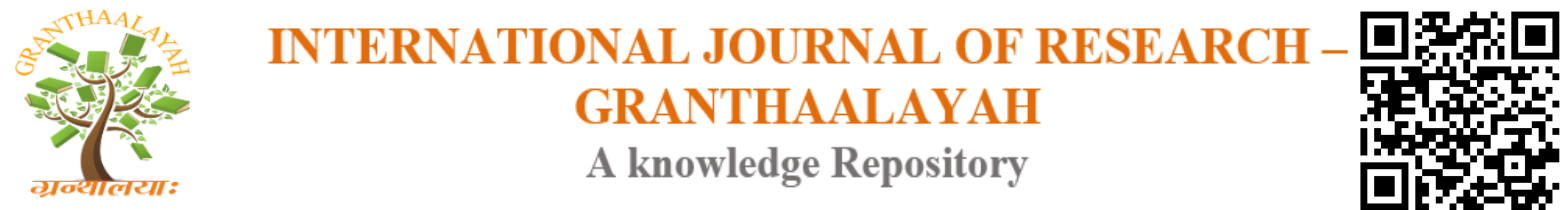

Science

\title{
SCREENING OF Andrographis Paniculata EXTRACT FOR ANTIOXIDANT AND GENOTOXIC ACTIVITIES
}

\author{
Dr. R.C. Agrawal 1, Prachi Pandey ${ }^{2}$ \\ ${ }^{1,2}$ Priyamvada Birla Cancer Research Institute Satna, India
}

\begin{abstract}
Andrographis paniculata is an important medicinal plant which has been used to treat various ailments. The present study was undertaken to analyze the phytochemical compounds and evaluated the antioxidant and genotoxic potential of Andrographis paniculata leaves and whole plant extracts. Phytochemical compounds analyzed by qualitative and quantitative analysis of methanol extracts of the leaves and whole plant extracts which showed the presence of Alkaloids, Carbohydrate, Resins, Saponins, Flavonoid, Steroids, Glycosides and Tannin. Quantitative analysis were also conducted to determine the amount of Alkaloids, Flavonoids, Saponins and Tannin by HPTLC Finger printing methods in A. paniculata (A.P.) leaves and whole plant .The Antioxidant activity of A. paniculata Methanolic extract was evaluated by Fenton methods which showed the dose dependent Inhibition of TBARS formation. The Genotoxicity was evaluated by Micronucleus Assay. The dose dependent prevention of bone marrow micronucleus formation by Andrographis paniculata leaves and whole plant extracts was observed. Therefore, Andrographis paniculata leaves and whole plant extract caused antioxidant and genotoxic potential.
\end{abstract}

Keywords: Andrographis Paniculata; Phytochemical; Antioxidant; Micronucleus; HPTLC.

Cite This Article: Dr. R.C. Agrawal, and Prachi Pandey. (2019). "SCREENING OF ANDROGRAPHIS PANICULATA EXTRACT FOR ANTIOXIDANT AND GENOTOXIC ACTIVITIES." International Journal of Research - Granthaalayah, 7(6), 132-142. https://doi.org/10.29121/granthaalayah.v7.i6.2019.780.

\section{Introduction}

Plants have been an important source of medicine to living organism for thousands of years. Plants are contemplated not only as dietary supplement to living organism but also traditionally used for treatment of many health problems ${ }^{1}$. Andrographis is an important genus of the Acanthaceae family that is medicinally important taxa containing 26 species. Andrographis paniculata is also called as Kalmegh or "King of Bitters." This plant is an extremely bitter in taste that is used to treat liver disorders, bowel complaints of children, colic pain, common cold and upper respiratory tract infection ${ }^{2,3,4}$. It is also used for the treatment of snake bite, bug bite, diabetes, dysentery, fever, and malaria ${ }^{5}$. Whole plant leaves and roots are also used as a folklore remedy for different diseases in Asia and Europe. AP has been reported to have a broad range of pharmacological 
effects including anticancer, antihepatitis, antihyperglycemic, hepatoprotective, antiinflammatory, antimicrobial, antidiarrheal, cardiovascular, cytotoxic, anti-HIV, immunostimulatory, and sexual dysfunctions ${ }^{6}$. Andrographis paniculata is used in Asia from centuries in traditional medicine to treat gastrointestinal (GI) tract and respiratory infectious diseases. It has been reported that Andrographis has a broad range of pharmacological effects ${ }^{7}$. It has been suggested to safe in controlled clinical trials report for treating upper respiratory tract infections. It also showed significant cardio protection by inducing antioxidant activity in myocardium $^{8}$. Cytotoxic activity against cancer cell lines has been reported by Compounds of Andrographis paniculata ${ }^{9}$. Antimicrobial activity against eleven bacterial strains by ethanol extract of Andrographis paniculata have been reported ${ }^{10}$. Andrographolide have been reported to hypoglasmic activity in rats ${ }^{11}$. Antiulcer activity was reported in duodenal ulcer model in rats ${ }^{12}$. Hepatoprotective effect was reported on acetaminophen induced hepatotoxicity in albino rats ${ }^{13}$. An andrographolide was also reported to induce apoptosis in TD-47 human breast cancer cell line in a time and concentration-dependent manner by increase expression of p53, bax, immuno histochemical parameters such as caspase- 3 and decrease expression of bcl- $2^{8}$. Andrographis paniculata ${ }^{14}$. Dry leaf powder was reported to cause spermatogenesis, cessation of degenerative changes in the seminiferous tubules. The extract also produced significant muscarinic activity, which accounts for its antivenom effects ${ }^{15}$.Many of the conditions commonly treated with Andrographis paniculata in traditional medical systems are important, which requires further investigations for benefit in cancer treatment.

\section{Materials and Methods}

\section{Chemicals}

All the Materials and Reagents used for the study were purchased from CDH, Renchem and HiMedia Ltd., India.

\section{Animals}

The experimental study was conducted on random bred, 6-7 weeks old and 24- 28 gm body weight bearing, male Swiss albino mice. Animals were maintained under controlled conditions of temperature $\left(24 \pm 3^{0} \mathrm{C}\right)$ and light (Light: dark, $10 \mathrm{hrs:} 14 \mathrm{hrs}$.). The animals were provided with standard mice feed and tap water ad libitum.

\section{Preparation of Andrographis paniculata Leaves and Whole Plant Extract}

Plant material of Andrographis paniculata was collected and the specimen was authenticated by the botanist of Deendayal Research Institute, Chitrakoot, Satna, Madhya Pradesh(India). The noninfected leaves and whole Plant was washed, air dried, powdered and extracted separately using $50 \%$ methanol in a separating funnel. Extract thus obtained were vacuum evaporated into powder. These extract was again dissolved in DDW immediately prior topical application.

\section{Preliminary Phyto-Chemical Screening}

\section{Alkaloids}

1 gram of dried powder was added with $10 \mathrm{ml}$ of $1 \mathrm{M}-\mathrm{HCl}$ and ultrasonicated for $15 \mathrm{~min}$ at $30^{\circ} \mathrm{C}$. The mixture was filtered and $3 \mathrm{ml}$ of filtrate was treated with few drops of either Dragendorff's 
reagent or Mayer's reagent or Wagner's reagent. Orange red, creamy white or reddish brown precipitate indicated the presence of alkaloids.

\section{Carbohydrate}

Anthrone's test: Take $1 \mathrm{ml}$ of sample in test tube and take $1 \mathrm{ml}$ of distilled water in another tube as control. Add $2 \mathrm{ml}$ of anthrone reagent to all the tubes. Mix thoroughly all the content of the tube. Observe for color change in bluish green. That indicates all carbohydrate give test positive result. Fehling's test: Filtrates were mixed with equal volume of Fehling's A and Fehling's B solutions and heated. Formation of brick red precipitate of cuprous oxide indicated the presence of reducing carbohydrate.

\section{Proteins}

Biuret test: To $0.5 \mathrm{mg}$ of extract equal volume of $40 \% \mathrm{NaOH}$ solution and two drops of one percent copper sulphate solution was added. The appearance of violet colour indicates that the presence of protein.

\section{Resins}

$10 \mathrm{ml}$ of distilled water were added to $1 \mathrm{~g}$ of dried powder, and ultrasonicated for $15 \mathrm{~min}$ at $30^{\circ} \mathrm{C}$. The mixture was filtered. Occurrence of turbidity showed the presence of rasins.

\section{Saponins}

About $0.5 \mathrm{mg}$ of the extract was shaken with five $\mathrm{ml}$ of distilled water. Formation of frothing (appearance of creamy miss of small bubbles) shows that the presence of saponins.

\section{Starch}

Small quantity of extract was taken and add 2-3 drop of iodine solution on it. Observe the colour of solution. Blue black colour indicates the presence of starch.

\section{Flavonoids}

Ferric chloride test: Test solution when treated with few drops of Ferric chloride solution would result in the formation of blackish red color indicating the presence of flavonoids.

Alkaline reagent Test: Test solution when treated with sodium hydroxide solution, shows increase in the intensity of yellow color which would become colorless on addition of few drops of dilute Hydrochloric acid, indicates the presence of flavonoids.

\section{Steroids}

$2 \mathrm{ml}$ of chloroform and concentrated $\mathrm{H}_{2} \mathrm{SO}_{4}$ were added with the $5 \mathrm{ml}$ aqueous plant crude extract. In the lower chloroformlayer red color appeared that indicated the presence of steroids.

\section{Glycoside}

Borntrager s Test: About five mg of the extract was boiled with $10 \% \mathrm{HCl}$ for few minutes in a water bath. It was filtered and allowed to cool. Equal volume of $\mathrm{CHCl} 3$ was added to the filtrate. Few drops of $10 \% \mathrm{NH} 3$ were added to the mixture and heated. Formation of pink colour indicates that the presence Glycosides. 


\section{Tannin}

Lead acetate test: To the test solution, a few drops of $10 \%$ lead acetate solution were added. Precipitate formation indicated the presence of tannin.

Ferric chloride test: To the test solution, a few drops of ferric chloride solution were added.an intense green, purple, blue or black colour indicated the presence of Tannin.

\section{HPTLC Fingerprint Profile}

Sample preparation: Took $100 \mathrm{~g}$ of drug in $250 \mathrm{ml}$ stoppered conical flask and extracted with $100 \mathrm{ml}$ alcohol for $24 \mathrm{hrs}$. by maceration technique with occasional shaking. Decant the extract and make up to $100 \mathrm{ml}$ in volumetric flask.

Solvent system: Toluene: Ethyl Acetate (7:3)

Visualization: under 254nm; 366nm, and after derivatization $366 \mathrm{~nm}$ and at visible

Light (Image given in Annexure -1) \& Major spots Rf Values given

Annexure-2)

Derivatizing reagent: $5 \%$ Methanolic Sulphuric Acid

\section{Antioxidant Activity}

Antioxidant activity of Andrographis paniculata Leaves and While Plant extract (10-100 $\mu \mathrm{g} / \mathrm{ml})$ were determined by De-oxyribose Method (Fenton Reaction) of Halliwell et al., (1987). The hydroxyl radical attacked to deoxyribose and initiated a series of reaction that eventually resulted in the formation of Thiobarbeturic Acid Reaction Substances (TBARS).

\section{Micronucleus Asaay}

It was done by the method reported by Schmid (1975) ${ }^{17}$, modified by Aron et al ${ }^{18}$ and standardised by us ${ }^{19}$ (Agrawal etal ,1998). In Micronucleus Assay, the extract of Andrographis paniculata Leaves and Whole plant at the volume of $0.2 \mathrm{ml}$ at different dose level such as 1000. 1500, 2000 $\mathrm{mg} / \mathrm{kg}$ body weight was injected $24 \mathrm{hrs}$ before the treatment of Cyclophoshamide, to three animals. Singlre ip. Injection of $50 \mathrm{mg} / \mathrm{kg}$ Cyclophasphamide in $0.9 \%$ saline was injected 24 hours before the Andrographis extract treatment. The animals were sacrificed by cervical dislocation and bone marrow cells were harvested. The slides were prepared essentially as described by Schmid (1975) After staining with May-Gruenwald and Giemsa Stain, a total 1000 cells were scored at the magnification of X $1000(100 \times 10 x)$ for each group. The data are expressed as the average number of micro nucleated cells polychromatied erythrocytes cells (PCE) cells / animals.

\section{Results and Discussions}

The therapeutic properties of medicinal plants are perhaps due to the presence of various secondary metabolites that are phenols, flavonoids, alkaloids, glycosides, steroids, saponins etc. The Leaves and Whole plant of Andrographis paniculata extract have revealed the presence of Alkaloids, Carbohydrate, Resins, Saponins, Flavonoid, Steroids, Glycosides and Tannin. Protein and Starch are not present in the extract. The result Preliminary phyto-chemical screening of Andrographis paniculata Leaves \& Whole plant Extrat shown in Table No.-1. 
Table 1: Preliminary phyto-chemical screening of Andrographis paniculata Leaves \& Whole

\begin{tabular}{|c|c|c|c|c|}
\hline $\begin{array}{r}\text { S. } \\
\text { No. }\end{array}$ & $\begin{array}{c}\text { Name of } \\
\text { Experiments }\end{array}$ & Observation & $\begin{array}{c}\text { Paniculata } \\
\text { Leaves }\end{array}$ & $\begin{array}{r}\text { Paniculata } \\
\text { Whole Plant }\end{array}$ \\
\hline \multirow[t]{4}{*}{1.} & Alkaloids & & & \\
\hline & Mayer' test & Yellow colour appear & Present & Present \\
\hline & Wagner's test & Brown colour appear & Present & Present \\
\hline & Dragendorff's test & Orange colour appear & Present & Present \\
\hline \multirow[t]{3}{*}{2.} & Carbohydrate & & & \\
\hline & Anthrone's test & Dark green colour appear & Present & Present \\
\hline & Fehling's test & Brick red colour appear & Present & Present \\
\hline \multirow[t]{3}{*}{3.} & Proteins & & & \\
\hline & Bieuret's test & Green colour appear & Absent & Absent \\
\hline & Millon's test & White ppt are not appear & Absent & Absent \\
\hline 5. & Resins & Turbidity are seen & Present & Present \\
\hline 6. & Saponins & $\begin{array}{l}\text { Honey comb - like structure } \\
\text { are form }\end{array}$ & Present & Present \\
\hline 7. & Starch & Red colour is formed & Absent & Absent \\
\hline \multirow[t]{3}{*}{8.} & Flavonoid & & Present & Present \\
\hline & Ferric chloride test & Reddis pink colour is appear & Present & Present \\
\hline & $\begin{array}{l}\text { Alkaline reagent } \\
\text { test }\end{array}$ & $\begin{array}{l}\text { On addition of dilute acid } \\
\text { yellow colour disappear }\end{array}$ & Present & Present \\
\hline \multirow[t]{2}{*}{9.} & Steroid & & & \\
\hline & $\begin{array}{l}\text { Salkowski’s } \\
\text { reaction }\end{array}$ & $\begin{array}{l}\text { A red colour is disappear in } \\
\text { the chloroform layer }\end{array}$ & Present & Present \\
\hline \multirow[t]{2}{*}{10.} & Glycoside & & & \\
\hline & Borntrager's Test & Colour is change & Present & Present \\
\hline \multirow[t]{2}{*}{11.} & Tannin & Greenish colour appear & Present & Present \\
\hline & $\begin{array}{l}\text { a) Lead acetate } \\
\text { Test }\end{array}$ & $\begin{array}{l}\text { Reddish brown bulky ppt. are } \\
\text { formed }\end{array}$ & Present & Present \\
\hline
\end{tabular}

\section{Quantitative Phyto-chemical Analysis}

The quantitative analysis that shows the percentage of Alkaloids, Saponins, Flavonoids, and Tannin present in extract. The result of Quantitative Phyto-chemical Analysis of Andrographis paniculata Whole plant \& Leaves extract shown in Table No.-2.

Table 2: Quantitative Phyto-chemical Analysis of Andrographis paniculata Whole plant \& Leaves extract

\begin{tabular}{|l|l|l|l|}
\hline S. No. & Name of tests & \multicolumn{1}{|c|}{$\begin{array}{c}\text { Andrographis paniculata } \\
\text { Leaves }\end{array}$} & $\begin{array}{c}\text { Andrographis paniculata } \\
\text { Whole Plant }\end{array}$ \\
\hline $\mathbf{1}$ & Alkaloids & $1.7642 \%$ & $2.28 \%$ \\
\hline $\mathbf{2}$ & Flavonoids & $12.13 \%$ & $13.02 \%$ \\
\hline $\mathbf{3}$ & Saponins & $3.51 \%$ & $3.79 \%$ \\
\hline $\mathbf{4}$ & Tannin & $5.12 \%$ & $5.39 \%$ \\
\hline
\end{tabular}




\section{HPTLC Fingerprint}

In HPTLC (High Performance Thin Layer Chromatography) fingerprinting analysis bands were observed on the HPTLC plates and the Rf values were calculated, where Rf value is Retention factor value. The observed fingerprint, rather than the presence of the compounds, represents a unique pattern and is given by a set of Rf values and the specific colours observed for these compounds. (Fig $1 \& 2$ )



$254 \mathrm{~nm}$ before derivatization At $366 \mathrm{~nm}$ before derivatization At Daylight before derivatization

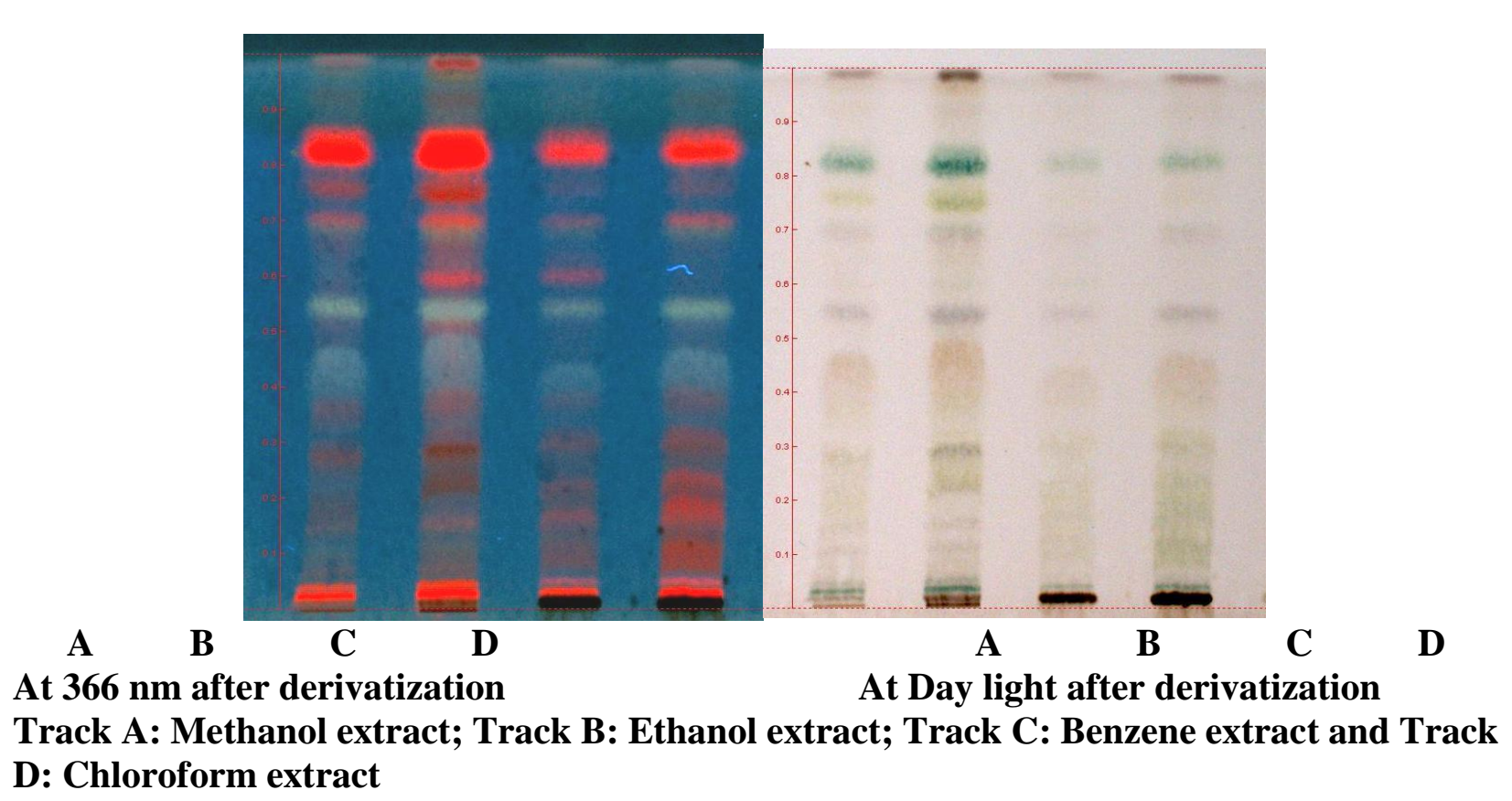

Figure 1: HPTLC Fingerprint Profile of Andrographis paniculata (Leaves) 


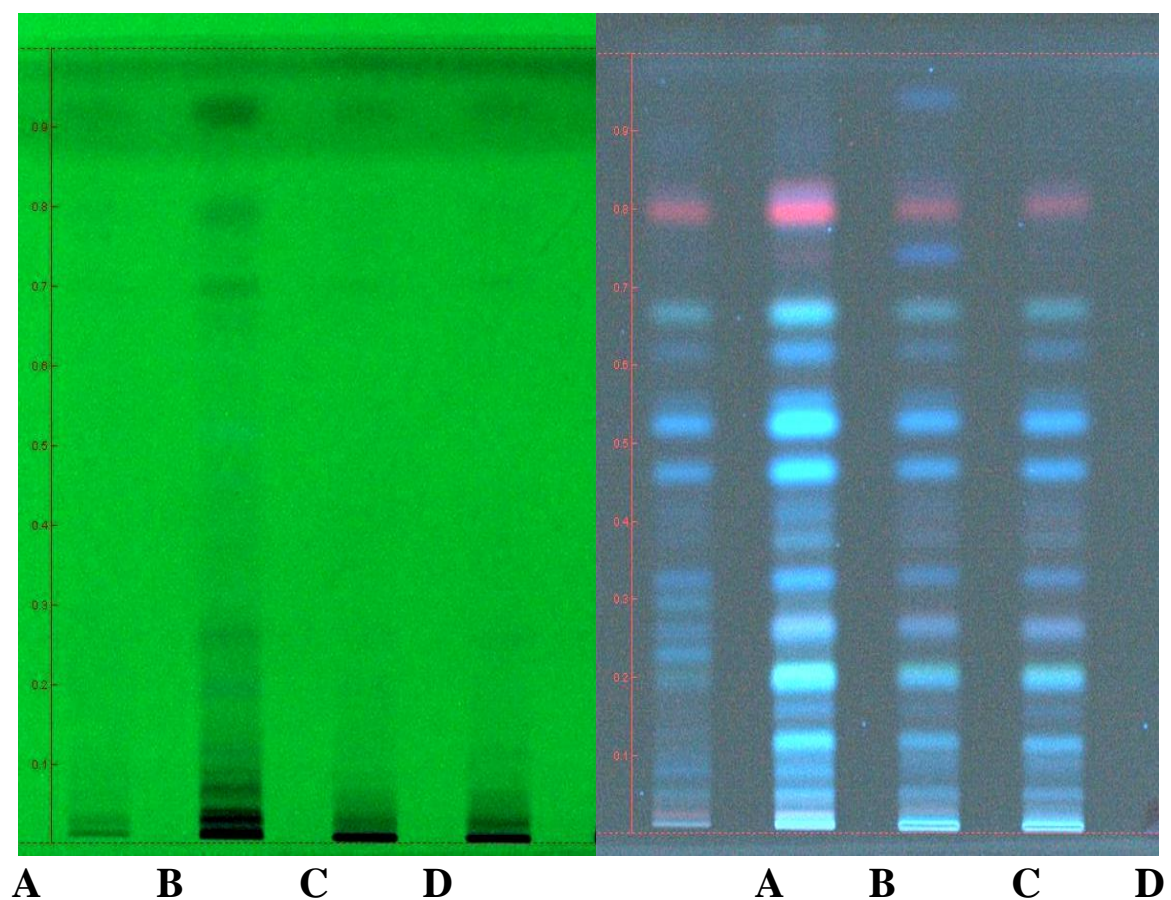

At $254 \mathrm{~nm}$ before derivatization

At $366 \mathrm{~nm}$ before derivatization

A
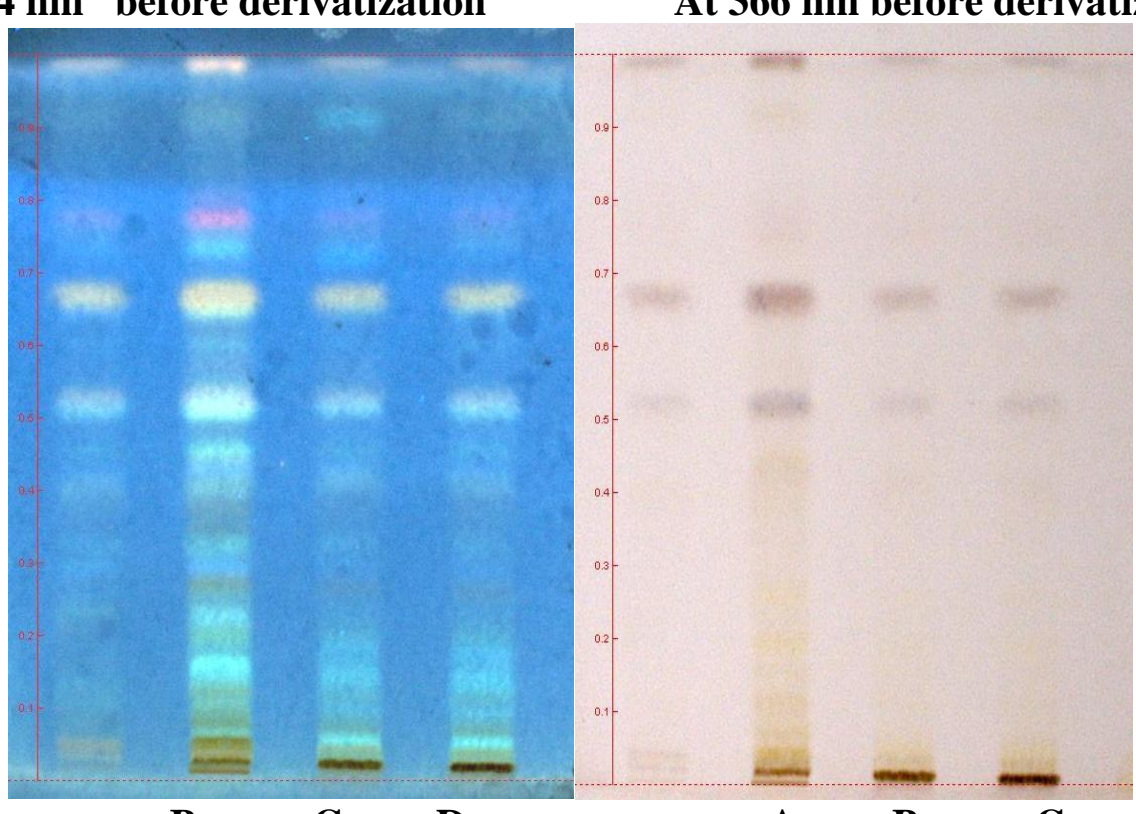

B C D

At $366 \mathrm{~nm}$ after derivatization

At Day light after derivatization

D

Methanol extract; Track B: Ethanol extract; Track C: Benzene extract and Track D: Chloroform Extract

Figure 2: HPTLC Fingerprint Profile of Andrographis paniculata (Whole plant)

\section{Antioxidant Activity}

The free radical scavenging capacity of the methanolic extract of Andrographis paniculata Leaves and Whole palnt extract were determined by using TBARS method. A. paniculata showed 
antioxidant activity when compared with Ascorbic acid that is used as positive control. The dose of different concentration of $A$. paniculata Leaves and Whole plant extract were observed. The TBARS values were compared with Ascorbic acid. (Table No.-3)

Table 3: Antioxidant Activity of Methanolic extract of Andrographis paniculata and Ascorbic acid as standard

\begin{tabular}{|l|l|l|l|l|}
\hline S.No. & \multicolumn{2}{|c|}{$\begin{array}{c}\text { Concentration } \\
(\boldsymbol{\mu g} / \mathbf{m l})\end{array}$} & \multicolumn{3}{|c|}{\begin{tabular}{c} 
\% of Inhibition (TBARS) \\
\cline { 3 - 5 }
\end{tabular}} & $\begin{array}{c}\text { Ascorbic } \\
\text { acid }\end{array}$ & $\begin{array}{c}\text { A.paniculata } \\
\text { Leaves extract }\end{array}$ & $\begin{array}{c}\text { A.paniculata Whole } \\
\text { plant extract }\end{array}$ \\
\hline 1 & 10 & 18.54 & 10.11 & 4.25 \\
\hline 2 & 20 & 23.09 & 21.14 & 10.36 \\
\hline 3 & 30 & 30.71 & 30.96 & 19.17 \\
\hline 4 & 40 & 34.67 & 34.38 & 31.2 \\
\hline 5 & 50 & 42.58 & 33.25 & 21.99 \\
\hline 6 & 60 & 50.71 & 37.36 & 37.96 \\
\hline 7 & 70 & 56.71 & 47.98 & 46.25 \\
\hline 8 & 80 & 61.13 & 41.54 & 53.58 \\
\hline 9 & 90 & 71.77 & 52.05 & 59.33 \\
\hline 10 & 100 & 79.47 & 65.04 & 81.06 \\
\hline
\end{tabular}

\section{Micronucleus Assay}

In the Micronucleus Assay Cyclophasphamide used as clastogenand anticlastogenic effect of $A$. paniculata has been observed in mice bone marrow cells (Table 3 ). A reduce number of micronuclei were seen in $A$. paniculata Leaves and Whole plant extract along with Cyclophosphamide as compared the Cyclophosphamide alone. The dose of 1000, 1500, 2000 $\mathrm{mg} / \mathrm{kg}$ body weight showed the reduction of micronucleus formation in PCE cell of bone marrow. The PCE/NCE ratio of $A$. paniculata Leaves and Whole palnt was increased as compare to Cyclophasphamide alone. (Table No. - 4)

Table 4: Effect of A. paniculata leaves and whole plant extract on Micronucleus (MN) formation induced by Cyclophosphamide (CP) in bone marrow cells of Swiss albino mice.

\begin{tabular}{|c|c|c|c|c|}
\hline Groups & $\begin{array}{c}\text { Treatment Doses ( } \mathrm{mg} / \mathrm{kg} \\
\text { body weight) }\end{array}$ & $\begin{array}{l}\text { MNPCE } \\
\pm \text { SEM }\end{array}$ & $\begin{array}{c}\text { PCE/NCE } \\
\text { Ratio } \pm \text { SEM }\end{array}$ & $\begin{array}{l}\text { Protection \% } \\
\text { of CP induced } \\
\text { MN formation }\end{array}$ \\
\hline I & $\begin{array}{l}\text { Cyclophosphamide Alone } \\
(50 \mathrm{mg} / \mathrm{kg} \mathrm{b.wt)}\end{array}$ & $4.25 \pm 1.5$ & $0.76 \pm 0.02$ & - \\
\hline \multicolumn{5}{|c|}{ A. paniculata leaves } \\
\hline II & $\begin{array}{l}\text { A. paniculata leaves alone } \\
(1000 \mathrm{mg} / \mathrm{kg} \text { b.wt })\end{array}$ & $0.5 \pm 0.57$ & $0.77 \pm 0.02$ & - \\
\hline III & $\begin{array}{l}\text { A. paniculata leaves } \\
(1000 \mathrm{mg} / \mathrm{kg} \mathrm{b.wt})+\mathrm{CP} \\
(50 \mathrm{mg} / \mathrm{kg} \mathrm{b.wt})\end{array}$ & $2.0 \pm 0.81$ & $0.88 \pm 0.08$ & 52.95 \\
\hline IV & $\begin{array}{l}\text { A. paniculata leaves } \\
(1500 \mathrm{mg} / \mathrm{kg} \mathrm{b.wt})+\mathrm{CP} \\
(50 \mathrm{mg} / \mathrm{kg} \mathrm{b.wt)}\end{array}$ & $1.0 \pm 0.57$ & $1.02 \pm 0.01$ & 76.48 \\
\hline
\end{tabular}




\begin{tabular}{|c|c|c|c|c|}
\hline $\mathbf{V}$ & $\begin{array}{l}\text { A. paniculata leaves } \\
(2000 \mathrm{mg} / \mathrm{kg} \text { b.wt })+C P \\
(50 \mathrm{mg} / \mathrm{kg} \text { b.wt })\end{array}$ & $0.5 \pm 0.57$ & $1.10 \pm 0.04$ & 88.24 \\
\hline \multicolumn{5}{|c|}{ A. paniculata whole Plant } \\
\hline VI & $\begin{array}{l}\text { A. paniculata whole Plant } \\
\text { Alone }(1000 \mathrm{mg} / \mathrm{kg} \mathrm{b.wt})\end{array}$ & $0.5 \pm 0.57$ & $0.67 \pm 0.99$ & - \\
\hline VII & $\begin{array}{l}\text { A. paniculata whole Plant } \\
(1000 \mathrm{mg} / \mathrm{kg} \text { b.wt })+\text { CP } \\
(50 \mathrm{mg} / \mathrm{kg} \mathrm{b.wt})\end{array}$ & $2.25 \pm 0.5$ & $0.76 \pm 0.11$ & 47.06 \\
\hline VIII & $\begin{array}{l}\text { A. paniculata whole Plant } \\
(1500 \mathrm{mg} / \mathrm{kg} \mathrm{b.wt})+\mathrm{CP} \\
(50 \mathrm{mg} / \mathrm{kg} \text { b.wt })\end{array}$ & $1.5 \pm 0.57$ & $1.21 \pm 0.41$ & 64.71 \\
\hline IX & $\begin{array}{l}\text { A. paniculata whole Plant } \\
(2000 \mathrm{mg} / \mathrm{kg} \text { b.wt })+C P \\
(50 \mathrm{mg} / \mathrm{kg} \mathrm{b.wt})\end{array}$ & $1.0 \pm 0.81$ & $1.06 \pm 0.05$ & 76.48 \\
\hline
\end{tabular}

PCE - Polychromatic erythrocytes, NCE - Normochromatic erythrocytes, MNPCE Micronucleated Polychromatic erythrocytes

\section{Discussion and Conclusions}

The preliminary phytochemical screening tests may be helpful in the identification of the bioactive principles and may lead to drug discovery and development. These tests facilitates their quantitative estimation and qualitative separation of pharmacologically active chemical compounds. The secondary metabolites or phytochemicals such as alkaloids, flavonoids, glycosides, phenols, saponins, sterols etc have medicinal value for eg. Saponins have hypotensive and cardiode pressant properties. Glycosides used for the treatment of congestive heart failure and cardiac arrhythmia ${ }^{20}$ Phenolics are major group of compounds that are flavonoids and Tannin, that act as free radical scavengers or primary antioxidants. Our phytochemical screening of Andrographis paniculata. give ideas regarding various secondary metabolites present in leaves and whole plant. Phytochemical showed the presence of glycosides, steroidal compounds, flavonoids, and saponins. Qualitative densitometric HPTLC fingerprint profile of methanolic extract can provide standard fingerprints and can be used as a reference for the identification and quality control of the fruit. The present study will provide the information with respect to identification and authentication of Andrographis paniculate.

In present study leaves and whole plant of Andrographis paniculata methanolic extracts showed antioxidant activity in dose dependent manner. The antioxidant activity of methanolic extract of leaves of $A$. paniculata was reported by decreased tissue malondialdehyde level and increased SOD levels due to its antioxidant and cerebro protective activity against cerebral infarction in Type II diabetic animal model ${ }^{21}$. The concentration ranged from 10 to $100 \mu \mathrm{g} / \mathrm{ml}$. The reducing power of the extracts may serve as a significant indicator of its potential antioxidant activity. The presence of reductones, break the free radical chain by donating a hydrogen atom. Reductones (i.e. antioxidants) presence in the sample extracts might cause the reduction of $\mathrm{Fe} 3+/$ Ferric Cyanide complex to Ferrous form which can be monitored by Spectrophotometer ${ }^{22}$ 
The present study showed that Andrographis paniculata extract caused the dose dependent inhibition of micronucleus formation in bone marrow cells of mice. This plant can be studied furthermore to know their biological effects which could be a helpful in the treatment and controlling of various diseases.

\section{Acknowledgements}

The authors are thankful to Dr. S. K. Maheshwari, Director, PBCRI, Satna for providing facility to carry out the bove work.

\section{References}

[1] Newman DJ, Cragg GM and Snader KM. The influence of natural products upon drug discovery. Natural Product Reports 2000; 17(3): 215-234.

[2] Negi AS, Kumar JK, Luqman S, Sbanker K, Gupta MM, Kbanuja SPS: Recent advances in plant hepatoprotectives: a chemical and biological profile of some important leads. Med Res Rev 2008, 28(5):821.

[3] Roxas M, Jurenka J: Colds and influenza: A review of diagnosis and conventional, botanical and nutritional considerations. Altern Med Rev 2007, 12:25-48.

[4] Kligler B, Ulbricht C, Basch E, Kirkwood CD, Abrams TR, Miranda M, Singh Khalsa KP, Giles M, Boon H, Woods J: Andrographis paniculata for the treatment of upper respiratory infection: a systematic review by the natural standard research collaboration. Explore 2006, 2(1):25-29.

[5] H. Burkill, W. Birtwistle, F. Foxworthy, J. Scrivenor, and J. Watson, A Dictionary of the Economic Products of the Malay Peninsula, Ministry of Agriculture and Co-operatives, Kuala Lumpur, Malaysia, 1966

[6] Sanower Hossain, Md. Zannat Urbi,1 Abubakar Sule,2 and K.M. Hafizur Rahman3; Andrographis paniculata (Burm. f.) Wall. ex Nees: A Review of Ethnobotany, Phytochemistry, and Pharmacology; Hindawi Publishing Corporation, The Scientific World Journal Volume 2014, Article ID 274905, 28 pages

[7] Sandberg F. Andrographidis herba Chuanxinlian: A review. Gothenburg, Sweden: Swedish Herbal Institute. Available from the American BotanicalCouncil (USA), 1994.

[8] Ojha SK, Bharti S, Joshi S, Kumari S, Arya DS. Protective effect of hydroalcoholic extract of Andrographis paniculata on ischaemia-reperfusion induced myocardial injury in rats. Indian J Med Res. 2012;135: 414-21.

[9] Aditya, VSPK. Kumar, N L and Mokkapati, A. Evaluation of in vitro cytotoxicity of Andrographis paniculata, Duranta serratifolia and Albizzia lebbeck whole plant extracts by MTT assay against MCF-7 and HT-29 cell lines. Current Research in Microbiology and Biotechnology, 2014, 2 (2), 351-353.

[10] Mishra, US, Mishra, A., Kumari, R. Murthy, PN and Naik, B.S.Antibacterial activity of ethanol extract of Andrographis paniculata. Indian Journal of Pharmaceutical Sciences,2009, 71 ( 4) , 436438.

[11] Nugroho, Agung Endro Mohamad Andrie and Endang Lukitaningsih Antidiabetic and antihiperlipidemic effect of Andrographis paniculata (Burm. f.) Nees and andrographolide in highfructose-fat-fed rats. Indian J. Pharmacology, 2012 44(3), 377-381.

[12] Saranya, P, Geetha, A Antiulcer activity of Andrographis paniculata (Burm.f.) Wall. against cysteamine-induced duodenal ulcer in rats. Indian Journal of Experimental Biology, 2011, 49(7).

[13] Maleeka Begum, SF, Santhana Kumar, J and Swathi Balakrishnan, V, Antioxidant and hepatoproective effect of Andrographis paniculata against acetaminophen (paracetamol) induced hepatotoxicity in Albino rats . International Journal of Current Research 2011, 3, (12).64-68 
[14] Harjotaruno, Sukardiman Aty Widyawaruyanti,and Noor Cholies Zaini Apoptosis Inducing Effect of Andrographolide on TD-47 Human Breast Cancer Cell Line, African journal of traditional and complimentary alternative medicine, 2007, 4(3)345-351.

[15] Akbarsha MA, Murugaian P. Aspects of the male reproductive toxicity/male antifertility property of andrographolide in albino rats: effect on the testis and the cauda epididymidal spermatozoa. Phytother Res. 2000,14(6):432-435.

[16] Meenatchisundaram S, Parameswari G, Subbraj T, Suganya T, Michael A. Medicinal and Pharmacological Activities of Andrographis paniculata -Review. Ethnobotanical Leaflets, 2009, 13, 55- 58.

[17] Halliwell B, Gutteridge JM and Aruoma OI. The deoxy ribose method: A simple "test tube" assay for determination of rate constants for reactions of hydroxyl radicals. Analytical Biochemistry. 1987; 165: 215-219.

[18] Schmid, W., 1975. The micronucieus test. Mutation research, 31: 9-15.

[19] Aron C.S., R. Sorg, and D. Zimmer, 1989. The mouse bone marrow micronucleus test. Evaluation of 21 drug candidates. Mutation research, 223: 129-140.

[20] Agrawal R.C. and S. kumar, 1998. Prevention of cyclophosphamide induced micronucieus formation in mouse bone marrow by indole-3 carbinol. Food and clinical toxicology, 36: 975-977.

[21] Olaleye MT, Cytotoxicity and antibacterial activity of methanolic extract of Hibiscus sabdariffa. Journal of Medicinal Plants Research.2007; 1: 9-13.

[22] Radhika, P. Annapurna,A and Nageswara Rao,S, "Immunostimulant, cerebroprotective \& nootropic activities of Andrographis paniculata leaves extract in normal \& type 2 diabetic rats,"The Indian Journal of Medical Research, vol. 135, no. 5, pp. 636-641, 2012.

[23] Nair VD, Paneerselvam R, Gopi R. Studies on methanolic extract of Rawolfia species from Southern Western Ghats of India - In vitro antioxidant properties, characterization of nutrients and phytochemicals. Ind Crop Prod 2012; 39: 17-25.

*Corresponding author.

E-mail address: rcagrawal.pbcri@ gmail.com 